\title{
MYTHS AND CULTS OF ANCIENT TENEA
}

\author{
Mitos e cultos na antiga Tenea
}

\author{
Elena Korka ${ }^{1}$ \\ Aspasia Gioka ${ }^{2}$ \\ Antonio Corso ${ }^{3}$ \\ Konstantinos Lagos ${ }^{4}$ \\ Ioannis Christidis ${ }^{5}$ \\ Argyro Pissa ${ }^{6}$
}

\begin{abstract}
Since 2013, archaeological excavation have been carried out at Chiliomodi in the region of Corinth, where ancient Tenea was located. Ancient sources give us important information about the topography and location of the site with which important mythological traditions are associated, such as the myths of the Trojan cycle and the myth of Oedipus. According with ancient literary sources, the main deity of Tenea was the god Apollo. Archaeological excavations reveal important remains that inform us about Tenea's religious life.

Keywords: Tenea, Troy, Tenedos, Apollo Smintheus, Oedipus, padded dancers, Dionysus.

\section{RESUMO}

Desde 2013, escavações arqueológicas têm sido conduzidas no sítio de Chiliomodi na região de Corinto, onde se encontrava a antiga Tenea. Fontes antigas nos fornecem informações importantes sobre a topografia
\end{abstract}

We thank mrs Paraskevi Evaggeloglou as she has supervised the documentation of the objects presented.

1 Honorary director general of antiquities and cultural heritage, director of the excavation of ancient Tenea.

E-mail: ekorka@otenet.gr

2 Member of the Tenea project team. E-mail: aspasiagioka@yahoo.gr

3 Member of the Tenea project team. E-mail: antoniocorso@hotmail.com

4 Member of the Tenea project team. E-mail: calagus@yahoo.com

5 Member of the Tenea project team. E-mail: teneaproject@hotmail.com

6 Member of the Tenea project team. E-mail: teneaproject@hotmail.com 
e localização do sítio ao qual estão associadas importantes tradições mitológicas, como os mitos do Ciclo de Troia e os mitos de Édipo. De acordo com fontes literárias antigas, a principal divindade de Tenea foi o deus Apolo. As escavações arqueológicas revelam materiais importantes que informam sobre a vida religiosa de Tenea.

Palavras-chave: Tenea; Troia; Tênedos; Apolo Esminteu; Édipo; padded dancers; Dioniso.

Since 2013, a systematic archeological excavation is being carried out in Chiliomodi, Corinthian, which has revealed burial sites (Archaic, Hellenistic, and Roman), part of the city's central civic center, complexes of private and public building and a variety of movable finds belonging to ancient Tenea (fig. 1, 2 ,3) (KORKA, 2013, p. 305-311; KORKA, AGELARAKIS, 2018, p. 549-556; KORKA et al, 2019, p. 6-21; KORKA-EVAGGELOGLOU, 2019, p. 101-113; CORSO, KORKA, LEFANTZIS, 2020, p. 172-21). From the remains of the buildings, it is worth mentioning an area possibly connected to religious activities of Archaic times, an above-ground funerary monument of the Roman period and a Hellenistic cistern of ritual purposes ${ }^{7}$ (fig. 4) as well as a public bath complex of the Roman period ${ }^{8}$ (fig. 5).

Prior to the excavation, Tenea was little known ${ }^{9}$ and the information about it mostly before came from ancient sources. More specifically,

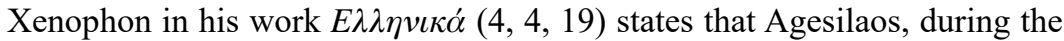
Corinthian war, left Argos and, to get to Corinth quickly, passed through

\footnotetext{
7 The monument consists of an above ground funerary hall and an ante-chamber, which communicates with the first hall through an entrance opening. In the main hall, on its three sides, there were five built graves. At the entrance traces of burnt material were found along with certain later children burials. Underneath the monument's ante-chamber, a rectangular underground cistern dating to the Hellenistic times was excavated. Inside it a large concentration of cremations, zooarchaeological material, a number of painted tiles, as well as pottery consisting mainly of burial offerings and ritual vessels were found. In a cremation outside the northwest corner of the cistern, a concentration of eleven intact miniature vessels of the 3rd century BC was found.

8 The public bath complex, extending to an area of $600 \mathrm{~m}^{2}$ and dating to the Roman period, is still partly excavated. The complex mostly contained warm spaces (caldarium) with underfloor heating with systems of hypocausts and galleries for their supply and cleaning (praefurnium), a hall with bathtubs which communicated with a swimming pool, and an off-center room with built-in benches and a colonnade. 9 A rescue excavation was carried out in the 1970s that identified a Roman workshop, building foundations, traces of an ancient wall and others, $\triangle \mathrm{EI} \Lambda \mathrm{AKH}, 1970$, p. 159-160. Also, ПАПАХРІ $\Sigma$ TО $\triangle \mathrm{OY} \Lambda$ OY, 1969, p. 103-104.
} 
a road outside Tenea ${ }^{10}$. Then the geographer Strabo $(8,380)$ gives the information that Tenea was a $\kappa \dot{\mu \eta}$, a town in Corinth, which due to its fertile plain and its location on the road to Argos, was considered a privileged place for permanent settlement. ${ }^{11} \mathrm{He}$ also states that when Corinth, in the 8th century BC, colonized Syracuse, most of the settlers were Teneans. He himself associates Tenea with Tenedos and Tenes, the son of Kyknos, and the cult of Apollo of Tenedos, and also mentions that Oedipus was raised in this city by the king of Corinth, Polyvos. The ancient traveler Pausanias also offers information about the topographic location of the ancient city, which was sixty stades (approximately 11 kilometers) away from the Teneatis Gate of Corinth. This is the area between the present villages of Chiliomodi


He also mentions that its inhabitants believed that they were Trojans, who were captured in Tenedos by the Greeks and then settled in Tenea with the permission of Agamemnon. For this reason they honored Apollo more than any other god (Pausanias, II, 5, 4; ПАПАХАTZH 2 , 1994, p. 87-88).

Thus, both ancient writers associate Tenea with Tenedos, the common denominator being the cult of Apollo. In the Iliad, Apollo appears as the main god of Troy ${ }^{12}$ and with the name Smintheus was worshipped as a local deity of the region. According to the "epos" (I, 37), the territory of the god extended to Chrysis, Killa and Tenedos and in this capacity he heard the calls of his priest, Chrysis, and sent the plague to the Achaeans (I, 43 -52) (LATACZ, 2005, note 59, p. 68). According to another mythical tradition (CIVITELLO, 2005, p. 261), the founder of Troy was Teukros, the son of Scamander. Father and son decided to establish a colony and sailed from Crete north, having first received an oracle from Apollo about their new place of residence. They followed the advice of the god, reached the shores of Asia Minor near Hellespont, founded Troy and honored Apollo Smintheus. Apollo, named Smintheus, was the patron god of agricultural

10 This road was famous in antiquity, because it shortened the Corinth-Argos route. There was also an ancient road from Kenchreai to Tenea, which could be used if one wanted to reach the Isthmus faster, without passing through Corinth. According to tradition, this was the road followed by the Dorians of Argos toward Corinth. ПАПАХАТZН $\Sigma, 1994$, p. 89.

11 According to Strabo, someone from Asia Minor once asked an oracle if it was prudent to settle in Corinth. The answer he received was: "The Corinthian is happy, but I wish I were a Tenean". Strabo, ibid.

12 Indicatively, in the Iliad (452 BC) it is mentioned that Apollo participated in the construction of the wall of Troy, when Priam's father, Laomedon, reigned. (LATACZ, 2005, note 59, p. 68). 
work because he was believed to exterminate mice ${ }^{13}$. According to researchers, the legend may be associated with a belief or a ritual ${ }^{14}$. It could be assumed that with the transfer of the cult to Apollo Smintheus from Tenedos to Tenea, the relevant agricultural beliefs and rituals that accompanied his cult were also transferred.

Strabo also associates Oedipus with Tenea. The myth of Oedipus belongs to the mythical circle of the Lavdakides, who were often mentioned in poetry and mythology until the end of Hellenistic and Byzantine times, adding, subtracting or combining the existing myths each time in a different way. The result of such a development is that many variations of this myth


Oedipus is a variation of the hero's myth ${ }^{15}$ and, according to M. Nilsson, its origin must be traced to folktales (1992, p. 113).

The essential points of the myth of Oedipus are considered to date from the Mycenaean Ages and were part of a series of epics for Thebes (NILSSON, 1992, p. 115). Through the accumulation of old and new data, research highlighted and isolated the main nucleus from the original form and structure of the myth. There are two main themes: the death of the fatherking by the hand of his son and the hero who saves the country from an evil and as a reward he receives the throne along with the queen. At the same time, the issue relates to the unintentional marriage of a son and a mother, with examples from Asia Minor. Furthermore, the researchers believe that this relationship may have been transferred to the myth by the relationship between the great Mycenaean goddess and her partner, emphasizing the natural role of the partner in reproduction, where the $<<$ paredros $>>$ was



13 According to another tradition, he took his name from the Trojan city of Sminthi (CIVITELLO, 2005, p. 261).

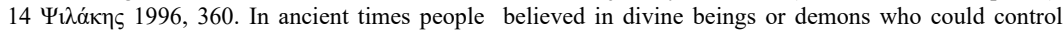
insects, harmful reptiles or other animals. They believed that with ceremonies and sacrificing animals they could ensure the good will of these powerful demons, who prevented insects or animals from harming humans. In the stage of the anthropomorphism of the gods these old demons appeared as qualities of the great gods. ПАПАХАTZH $\Sigma, 1998,267$. It is possible that Apollo replaced some pre-Hellenic deity. $\Psi \lambda \lambda \dot{\alpha} \kappa \eta \varsigma$ 1996, 360. For the presence of the word Smintheus on the plates of Linear B and the Minoan and Mycenaean presence on the coasts of Asia Minor during the Bronze Age, see CIVITELLO, 2005, p. 259-268.

15 It is similar to the myths of Perseus, Jason, Theseus, Pelias, Moses, Romulus and Remus and many others (SEGAL, 2001, p. 79). 
In addition to the above interpretations, the reference of Tenea as the place of Oedipus' upbringing may have concealed a historical nucleus and reflected on the relationships between Thebes, Corinth and Tenea in prehistoric times due to the very ancient source of the original myth. Archaeological evidence suggests that there may have been a prehistoric settlement on the hill of Agioi Asomatoi in Klenia, and it has been suggested that this area may be connected to the tradition that Oedipus was brought up



The traditional core of the myth may be connected to the transportation and installation of prisoners of Tenedos in Tenea, as Pausanias suggests. The issue is related to the kingdom from Agamemnon and the kingdom of Mycenae. According to the list of ships recorded by Homer in the Second Rhapsody of the Iliad, 29 kingdoms took part in the campaign against Troy. Agamemnon was the general, as he campaigned against Troy with more ships than all the other kings (100 ships) and, as recorded on the list, in his territory, among other areas, Corinth was included. Pausanias, also referring to the mythical hero of Corinth, Bellerefontis, considers that he was not a king with absolute power, but that was after he was dependent on Proetus and the Argives. He believes that even when Bellerefontis moved to Lycia, the Corinthians were still subjects to the rulers of Argos or Mycenae. They did not have their own army chief against Troy, but they took part with the Mycenaeans and those whom Agamemnon commanded (Pausanias, II, 2-4).

Archaeological evidence to date suggests that Corinth belonged to the Mycenaean sphere of influence during the Late Bronze Age. According to Pullen and Tartaron, it seems that Mycenae began to expand to southwest Corinthi, at least during the early Late Helladic period. The excavations in Tsoungiza and Zygouries confirmed the close relationship between the communities living there and Mycenae. Their ceramic production bears a strong resemblance to the LH IIIA ceramics of Mycenae. In addition, an extensive system of roads starting from Mycenae undoubtedly served to control the southwest of Corinth (PULLEN, TARTARON, 2007, p. 148). It has been argued that the failure to find a Mycenaean palace to this day may indicate the absence of a palace and, consequently, of a strong local government in the Corinthian region ${ }^{16}$. After the Bronze Age, Corinth developed into a powerful

16 Corinth was at that time one of the most powerful centers: on the one hand Mycenae and on the other Colonna in Aigina formed a powerful axis of influence at the time. PULLEN, TARTARON, 2007, 157-158. 
center due to its strategic location on the Gulf of Corinth, with its proximity through its port at Lechaion to the Adriatic Sea and Italy, which were sources of a new iron ore. Its key position in the new commercial areas network and the collection of tolls sent a once insignificant settlement areas to the top of the Greek city-states (PULLEN, TARTARON, 2007, p. 157-158).

In relevance to the cults of ancient Tenea, the archaeological data that we have at our disposal so far do not give clear evidence of the public and private cults that were practiced in this ancient city. This is because no relevant epigraphic testimony has been found. As a result, the information we offer regarding the cults are based on a plethora of mobile findings. These findings date from the Archaic, Hellenistic and Roman eras.

From the Archaic period, extremely important data for the worship of Dionysus comes from a unique askos, which was found at the burial of a child in a monolithic sarcophagus (Gr 2) of the period ${ }^{17}$. This burial dates from the first half of the 6th century B.C. and was very rich $^{18}$. In a prominent position in the ceramic cluster that was placed outside the grave, a double spouted askos was found with a rope handle.

The shape of this askos and a trifoil spout (fig. $6,7,8$ ) are a unique find for the Greek territory according to the archaeological data existing so far. The decoration is typical Corinthian of this period. At the top of the vase, between the spouts and under the handle, there is a hunting scene with two dogs running to catch a rabbit. The upper body is decorated with a frieze with a man riding a horse on one side and on the other four male figures are depicted as "padded dancers" or komasts dancing from left to right around a crater ${ }^{19}$ (fig. 9, 10, 11). Finally, a third frieze surrounds the lower part of the vase depicting a figure between two sphinxes, which alternate with panthers and stags, while on the other side of the frieze, under the scene with the padded dancers, a siren appears between two sphinxes. Iconographically, the theme of "padded dancers" is difficult to analyze (PEMBERTON, 2000, p. 86; PAYNE, 1931, p. 118; ZISKOWSKI, 2012, p. 212) and various interpretative approaches have

17 In 2013, during the excavation of ancient Tenea, and more specifically in area "Faneromeni-Kamareta", a rich child burial was found in a monolithic sarcophagus ( $\mathrm{Gr} 2$ ). This sarcophagus was located in an organized cemetery of archaic times, part of which came to light and consisted of five burials (Gr2, Gr3, Gr4, Gr, 5, Gr6), dating from the first half of the 6th century BC until the 3rd B C (KORKA, EVAGGELOGLOU, 2019, p. 103-105.

18 Inside the grave there were five intact vessels and outside the sarcophagus forty-eight intact vessels were also found. Ibid.

19 For the typology of the depiction of the komasts, see SEEBERG, 1971, p. 2. For painters, see SEEBERG, 1971, p. 59-62; AMYX, 1988, p. 101-118. 
been proposed. ${ }^{20}$ According to H. Payne, " the padded dancers "were a favorite subject from the latter part of the seventh century, but are unknown in the Protocorinthian and Transitional styles" (PAYNE, 1931, p. 118). ${ }^{21}$

Many scholars associate the "padded dancers" with various forms of early theater, such as the dance of "komos", satyric plays, and the first dithyramb. ${ }^{22}$ The iconographic association of these scenes with wine and Dionysus is reasonable, despite the actual absence of the figure of Dionysus in these scenes. ${ }^{23}$ The dance of the "padded dancers" has also been linked by scholars to the kordax. ${ }^{24}$ As Payne notes, "... the fact that the dancers are constantly grouped round a wine crater and have drinking - horns in their hands, combined with the fact of their presence in the company of Dionysos on at least two vases, leaves no doubt at all of their Dionysiac character". ${ }^{25}$

Early drama is connected to the Corinthian area. According to Herodotus (1.23), Arion composed the dithyramb, gave it this name and presented it in Corinth. As A. Lesky observes, the contribution of Arion consists in making the dithyramb a choral and lyrical artistic kind, and this happened in Corinth at the time of Periander. ${ }^{26}$ The fact is that the popular worship of Dionysus during the archaic period was particularly strengthened by many tyrants, who viewed the Dionysiac cult as the ideal basis for strengthening their power. For this reason, they promoted the cult of this god and used it as a weapon against the official religion of the aristocrats, who were their political opponents (ПАПАХАTZH $\Sigma, 1996$, p. 80). The similarity between komasts and satires may offer an explanation to link drama to "padded dancers". However, the komasts differ from the satyrs because they have no tails, horns, animal ears or masks, and rarely carry a raised phallus. In some cases the komasts appear together with satyrs (ZISKOWSKI, 2012,

20 For a brief overview of various interpretative approaches, see SEEBERG, 1971, ix. Also ZISKOWSKI, 2012, p. 214.

21 According to A. Ziskowski, "padded dancers appear on Corinthian pottery as early as the Transitional Period (630-615 BC) and as late as Corinthian I (570-550 BC). But it is during the Early Corinthian (615-590 BC) and Middle Corinthian (590-570 BC) stages that their iconographic production intensifies" (ZISKOWSKI, 2012, p. 212-213). For dating issues of Corinthian pottery, see, ibid., footnote 3. Also, BOARDMAN, 2001, p. 213-225.

22 ZISKOWSI, 2012, p. 214. SMITH, 2010, p. 2.

23 PEMBERTON, 2000, p. 87-88. Generally on the Archaic Corinthian vases there are no depictions of gods, especially compared to those existing in Attica. PEMBERTON, 2000, p. 87.

24 Payne 1931, p. 121. According to Payne, it is not clear whether the dancing of the komasts is the kordax. Ibid. 25 Ibid, p. 121.

26 LESKY, 1990, p. 329. 
p. 215). Of course, as we have seen, it is not possible to connect all komasts with the theater or worship of Dionysus, because the first examples were produced in a "pre-drama" scene. Nevertheless, their clothes, the act of dancing, the similarity to satyrs and their presence in scenes that include Dionysus or a symposium, represent some of the most important features that connect them to drama (ZISKOWSKI, 2012, p. 214-215).

Important information about the cults of Tenea from the Archaic to the Roman period is also offered by the sculptures and fragments of sculpture that have come to light in Tenea to this today.

Some of them come from early finds, others from illicit trafficking and some from the systematic excavation of Tenea by Dr E Korka. Three statues belong to the genre of the Kouroi and date from the Archaic period. Unfortunately, these Kouroi come from clandestine excavations. Two were confiscated in 2010. These two Kouroi (fig. 12) come from ancient Tenea and are now exhibited at the Archaeological Museum of Corinth. They are products of a Corinthian workshop and date around $530 \mathrm{BC} .^{27}$

The third kouros (fig. 13) was acquired in the 1840s by the Austrian ambassador to Greece at the time and was illegally exported, and it is now kept at the Glyptothek of Munich (STEWART, 1986, p. 54-70). It also comes from ancient Tenea and was sculptured by a more innovative Corinthian master. These three statues are true masterpieces and are among the best surviving examples of archaic Corinthian sculptures. It is not known if they were originally set up in sanctuaries or cemeteries, as their original locations are not exactly known.

Moreover, from the systematic excavation of Tenea a marble thigh of the left of a statue of a male sculpture was found in September 2019, near the Roman baths of Tenea (fig. 14, no. 2). It was associated with Archaic ceramics. The marble of this fragment looks Parian and its polishing is typical of the early $5^{\text {th }}$ century BC. Its quality is outstanding. ${ }^{28}$ The thigh looks similar to the corresponding parts of Apollo Omphalos type examples (fig. 15) (PAFUMI, 2002, p. 55-84). Perhaps this statue of Tenea was also an Apollo and may have remained in the temple of Apollo Teneatis, which is known by Strabo 8. 380. ${ }^{29}$

27 Both these kouroi may have been sculptured in the same Corinthian workshop and perhaps by the same master. 28 The thigh is well worked on the front and on both sides: this fact implies that the statue was characterized either by open legs or by one leg more advanced than the other.

29 The surface of the thigh is well preserved and not weathered, thus this statue, which had an approximate height of $1,60-1.65 \mathrm{~m}$. high, once stood inside a building. 
Other sculptures of marble statues of types, which are known from many examples especially in Delos (JOCKEY, 1998, p. 177-184) and in the Agora of Athens (STEWART, 2012, p. 267-342) and date from the late $2^{\text {nd }}$ century $\mathrm{BC}$ or in the early $1^{\text {st }}$ century $\mathrm{BC}^{30}$ were found at the excavation of Tenea in 2019. A fragment preserves a female right shoulder crossed by a strap, which probably implies the original presence of a quiver in the back of the statue: the right arm was raised, probably to take an arrow from the quiver (fig. 14, no. 5). Perhaps the statue is Artemis: the goddess might have been represented according to the Dresden (fig. 16) or Versailles or Malta types of this goddess, which are characterized by the action above of the right arm of the goddess. ${ }^{31}$ Another possibility is that it represents a fragment of a smaller Sciarra (fig. 17) or Sosikles copy of the Amazon. ${ }^{32}$ Another marble statue is female, what survives is the lower belly, bottom, pubes and thighs (fig. 14, no. 1). This section makes it clear that the statue was once a copy of the Cnidian Aphrodite (fig. 18), which was similar to the many marble statues of the late Hellenistic goddess in this style, which have been found in many places in the Aegean world (CORSO, 2015, p. 72-81).

Finally, a female torso of a headless marble statue was also found: the upper parts of the arms survive: the left arm was lowered, while the right arm was raised (fig. 14, no. 3). Thus, the statue was a miniature copy of the cult statue of Aphrodite made by Hermogenes of Cythera for the temple of Aphrodite in the Agora of Corinth. This goddess had her left arm lowered to hold the mirror, while her right arm was raised to wreath herself (fig. 19) (CORSO, 2015, p. 80-89).

These statuettes reveal the existence of copies of masterpieces by renowned important masters in Hellenistic Tenea from middle to end.

Moreover, reliefs were previously found in the area of ancient Tenea. Three of them probably concern the same monument, an altar from the Augustan period, and in particular the external sekos of this altar. Unfortunately, only one of these three reliefs is still extant.

30 These small sculptures are not fully polished but the natural brilliance of marble surfaces is preserved in some parts. There is not a clear distinction between the small bases and the marble statuettes on them. 31 About these types of Artemis, see CORSO, 2014, p. 121-123.

32 About these types of Amazons, see BOL, 1998. Another possibility is that this fragment represents a right foot. In that case, the thin strip would be that of the ground on which the foot is standing. 
One panel, totally preserved, is now kept at the Archaeological Museum of Corinth (fig. 20). It has a frame in the shape of a swastika maeander, which defines the central rectangle in relief from the left, right and above. The frame is slightly tapered from below to top. This swastika maeander is similar to the analogous pattern on the Ara Pacis (CONLIN, 1977, fig. 157). On the right side of the display panel, there is a semipillar which is topped by a Corinthian capital with the three rows of canon leaves and the high leaves at the corners. This type of capital is typical of the standard Corinthian capital pillars in the Augustan period (SAURON, 1993, p. 75-97).

In the center of the panel, the god Hermes is represented in relief. $\mathrm{He}$ is depicted in profile as he moves towards the right of the viewer. The remote model of his head is the Andros type of Hermes, which is attributed to the Praxitean environment around 340-330 BC (KAROUZOU, 1969, p. 143-157). The general scheme of the figure is taken from the CambridgeVatican type Hermes, known from the reliefs of these museums and dated from the end of the Hellenistic times (SEEBERT, 1990, p. 320, nos. 377-378 a-b). The presence of the sakkos for coins identifies the god as Mercurius (SIMON, 1992, p. 500-501) rather of Hermes. This panel must have been located on the left side of the spectator's sekos, because Hermes' movement toward the right of the spectator implies that the center of the monument was in this direction.

A fragment of a panel once preserved in the local Church of Agios Nikolaos in Klenia, but now lost, carries the same swastika maeander as the panel with Hermes and thus probably pertained to the same monument. It depicted in the middle Dionysos as a young god without beard, standing in full perspective, wearing himation and holding a thyrsus in his left hand (KORDOSIS, 1997, p. 576, fig. 23). Clearly this Dionysos is the Hope type of the god, conceived in the Praxitean environment at the end of Classical times and known thanks to paintings and late Classical reliefs, as well as several Roman copies (CORSO, 2000, p. 26-29).

Finally, a stone relief is placed on the walls of the main church of Chiliomodi, and it is said to have come from the ancient theatre of Tenea. The panel represents a young naked Dionysus, held by a Satyr (fig. 21). This type of symplegma is well known from many examples from many parts of the Hellenistic world and cover a chronological period from the end of the $4^{\text {th }}$ century BC until the $4^{\text {th }}$ century AD (POCHMARSKI, 1990, pls. 8-15; 22 ; 24-25; 28-29; 34-39; 41-43; 54-59; 61-82). The Dionysos of the Argos 
Archaeological Museum (SCHROEDER, 1989, 40, no. G 5, pl. 13), is also naked, with his right arm brought on top of his head and legs crossed and is dated to the end of the AD $2^{\text {nd }}$ century. Probably the same date should also apply to the relief of Tenea, which for this reason may be attributed to a workshop in Argive.

This example reveals the reception in Tenea of the imperial equivalent of a visual culture based on schemata nobilia. These sculptures can be used as evidence for a still tentative reconstruction of the pantheon of Tenea. The sculptures probably pertaining to images of Apollo and Artemis may suggest the importance of the Apollonean cult, which is also mentioned by Strabo stating that the Apollo Teneatis cult was the most important of this city.

Representations of deities in lamps, which were found mainly in the Tenea cemeteries, probably also provide clues for the deities that may have been worshipped. An interesting set of lamps comes from Roman tombs. Among them, three stand out. The first of them was found in a child's grave (Grave 15) next to the dead child's head (fig. 22). It bears a representation of the goddess Aphrodite, and two cupids on eachside of her, and is attributed to the end of the 1st century AD. It was made by the popular craftsman Lucius, as the signature on the base reveals. The goddess is depicted naked with a robe covering her right leg and the pubic area. With her right hand she touches a mirror, which is held by a cupid. To her left a second cupid holds an object, probably a wreath. The goddess is depicted in the Emerging Aphrodite type, which represents the birth of the goddess from the sea. This is a very popular type (NAGEL, 2010, p. 241), both inside and outside Greece, which is described in ancient texts as existing in monumental paintings. The chthonic nature of Aphrodite is derived from the attribute "Aphrodite of the Dead", which is better known in the Hellenistic and Roman times, but is considered to have ancient roots. This image may be the continuation of one of nature's great deities, who had control of fertility in relation to flora and fauna, while ruling the birth and death of every living being (ПАПАХАТZН $\Sigma$, 1996, p. 138). In Corinth, outside the old Kenchreai Gate, there was a large cemetery, with a forest, inside which there was a temple of Aphrodite with the attribute "black" due to its connection with the underworld (ПАПАХАTZH 2,1996 , p. 139-140).

The next lamp has a representation of Artemis Laphria, and is dated from the middle or end of the 2nd century AD (fig.23). The goddess is represented wearing a short tunic and robe. An altar is depicted behind her and she is accompanied by a dog. This lamp was also found at a burial 
(Grave 2) of three children, at the height of their feet. This iconographic type is known for its depictions on the coins of Domitian, Lucius Verus, Commodus and Caracalla (ПЕТРОПОҮ ОО , 1999, p. 81, note 430), and its inspiration may have been a cult statue of the goddess that existed in Patras. As a "hunter", Artemis maintained her strict character in historical times,


its reckless extermination. Gradually, Artemis became the guardian of all the animals and even fruits useful for human consumption. At the Laphria festival in Patrai, wild and domestic animals, even fruits, were burned in a big fire. These offerings were offered to the goddess so that in the following year she would give more abundance to the items that were burned in the fire

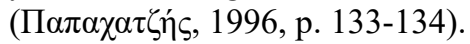

The third lamp bears a rare representation of the goddess Hygeia and is dated from the end of the 2nd-beginning of the 3rd century AD (fig.24). This lamp was also found at a child's burial (grave 29). The goddess is depicted with a maneuvering snake in her right hand, which she feeds from a bottle, which she holds in her left hand. The goddess is depicted according to her statues from the classical times (LEVENTI, 2003, p. 71), such as Hygeia Hope, Hygeia Broadlands / Conservatori, as well as her original cult statue from the sanctuary of Asclepius in Epidaurus, early 4th century BC.

We can also deduce important information about the deities, which were worshiped in the city from the coins of Tenea. More specifically, three coins are known today from the Tenea mint which allude to the local cults (KORKA, LAGOS, 2018, p. 199-211; 203-204; 2019, p. 349-362). All of these belong to the Roman Imperial period and were attained during the reign of Septimius Severus (193-211 AD). Two have the same inverted type of Dionysus standing left, wearing a short chiton and holding a thyrsus with the left hand and pouring wine from a cantharus with the right. The obverse of these coins carries either the portrait of Severus or his wife, Julia Domna. Although there are no literary sources mentioning a temple or sanctuary of Dionysus in Tenea, the fact that his image appears as a type of coin in two different but contemporary local editions probably shows that this cult would have been important in the region (fig. 25, 26).

The third coin issue has as obverse type a portrait of Julia Domna and on the reverse Artemis walking on the left holding with her left hand a bow and with the right taking an arrow from her quiver suspended on her back; while a hound at her feet is ready to attack (fig. 27). During the archaeological excavations of Tenea, a ceramic lamp of the Roman period 
was unearthed bearing as decoration a depiction of Artemis similar to the local coin issue. The type is reminiscent of Artemis Laphria, known mainly in Patras, Peloponnese. However, in the Tenea issue, Artemis is not static, as is the case for Laphria, but seems to be in motion. Therefore, we cannot exclude the possibility that Artemis depicted in the coin issue of Tenea is a hitherto unknown local type.

These issues of Tenea are today extremely rare with only two coins registered of the first one (Septimius Severus/Dionysus), three of the second (Julia Domna/Dionysus), and a unique coin of the third (Julia Domna/ Artemis). Until recently only the coins of the second edition were known, one in the British Museum and the other two in the Athens Numismatic Museum. All coins of the first and third issues appeared in coin auctions from 2006 outside Greece. These coins have no recorded provenances and appear to have been smuggled abroad as a result of illegal antiquities trade (Ibid).

An interesting find from the archaeological excavation of Tenea that may be related to the worship of the god Sarapis is an iron ring ${ }^{33}$ with a dark red precius stone (fig. 28). The ring was found in grave Gr 31 and dates between the 1 st century $\mathrm{BC}$ to the 1 st century $\mathrm{AD}$. It was found in the area of the fingers of the skeleton of the main burial, which belongs to a female aged 20-30 years ${ }^{34}$. The deity is depicted seated on a throne. It is a typical representation of the god Sarapis, who in his left hand holds a sceptre, while with his right he touches Cerberus, who is at his feet (STAMBAUGH, 1972, p. 14-22; TAKÁCS, 1995, p. 179-190; MARTENS, 2015,p. 53). The god is dressed in a tunic, which covers the upper part of the body, and a robe. His hairstyle seems to follow the standards of depiction of this deity (HILL, 1946 , p. 60-68). Sarapis' is depicted as a bearded man with rich curly hair, while on his head he wears an unadorned basket. The basket is a common feature in Sarapi's iconography and has been linked by many researchers to fertility or chthonic characteristics (STAMBAUGH, 1972, p. 14-22. MALAISE, 2009, p. 130-136).

According to written sources, Tenea's patron was Apollo Smintheus. The transfer of his worship from Tenedos and, more generally the coasts of Asia Minor to Tenea indicates the interactions between the two regions,

33 Its maximum diameter is $3.9 \mathrm{~cm}$ on the inner ring and $4.5 \mathrm{~cm}$ on the outside, while the dimensions of the seal stone are $3.5 \mathrm{~cm}$ long and $2.5 \mathrm{~cm}$ wide.

34 A similar ring of the same construction but with a different representation has been found in the painted tomb in Cheliotomylos, dating between the 1st century BC. And 1st century AD (SLANE, , 2017, pl. 77). 
which probably date back to prehistoric times. In fact, the relevant myth of the founding of Troy by Teukros and the establishment of the cult of Apollo Smintheus may indicate the Minoan origin of the god (CIVITELLO, 2005, p. 266). Since a temple dedicated to this god has not yet been excavated, the indications of his worship are indirectly derived from the surviving statues. In addition, it is interesting to note that the two kouroi mentioned above may have been offerings in an archaic temple (ПАПАХАТZH $\Sigma$, 1996, p. 173). In general, we hope that further excavations will provide additional data for the cults and religious practices of ancient Tenea.

\section{Captions}

Fig. 1 - Tenea. Map with sites.




Fig. 2 - Ancient road.



Fig. 3 - Domestic remains.
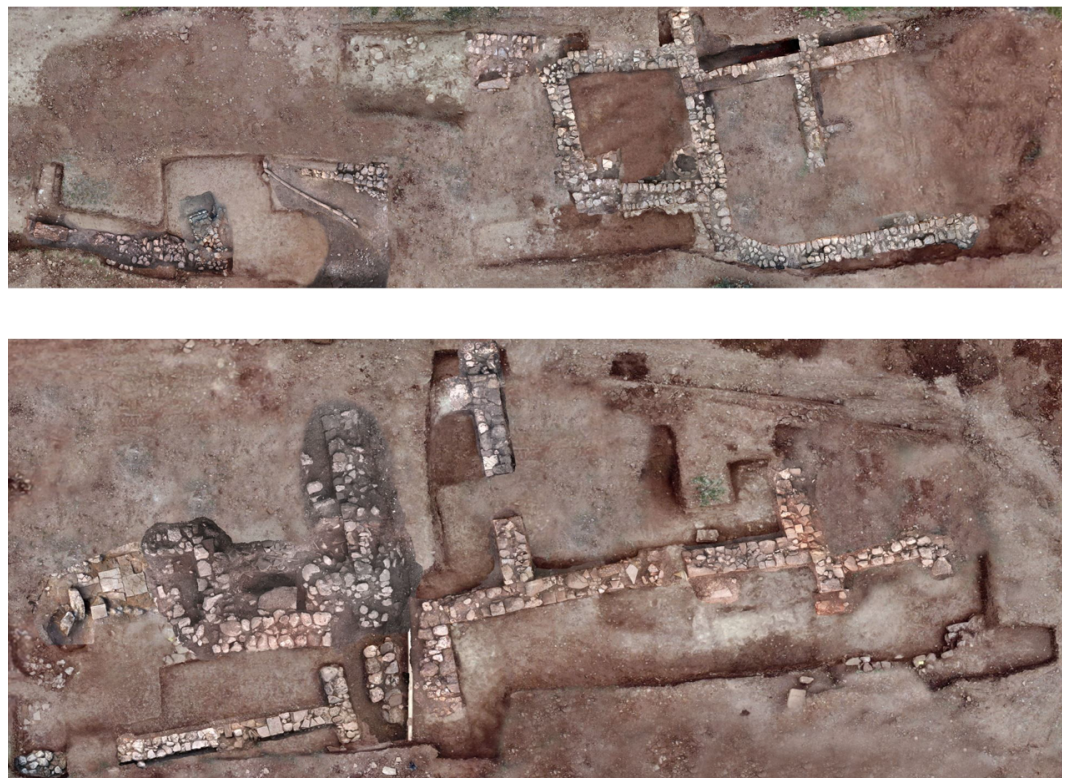

História: Questões \& Debates. Curitiba, v. 69, n. 1, p. 47-80, jan./jun. 2021. Universidade Federal do Paraná. ISSN: 0100-6932. DOI: http://dx.doi.org/10.5380/his.v00i0.000000 
Fig. 4 - Roman chamber tomb.



Fig. 5 - Roman bath complex.



História: Questões \& Debates. Curitiba, v. 69, n. 1, p. 47-80, jan./jun. 2021. Universidade Federal do Paraná. ISSN: 0100-6932. DOI: http://dx.doi.org/10.5380/his.v00i0.000000 
Fig. 6, 7 and 8 - The double spouted askos with a rope handle.
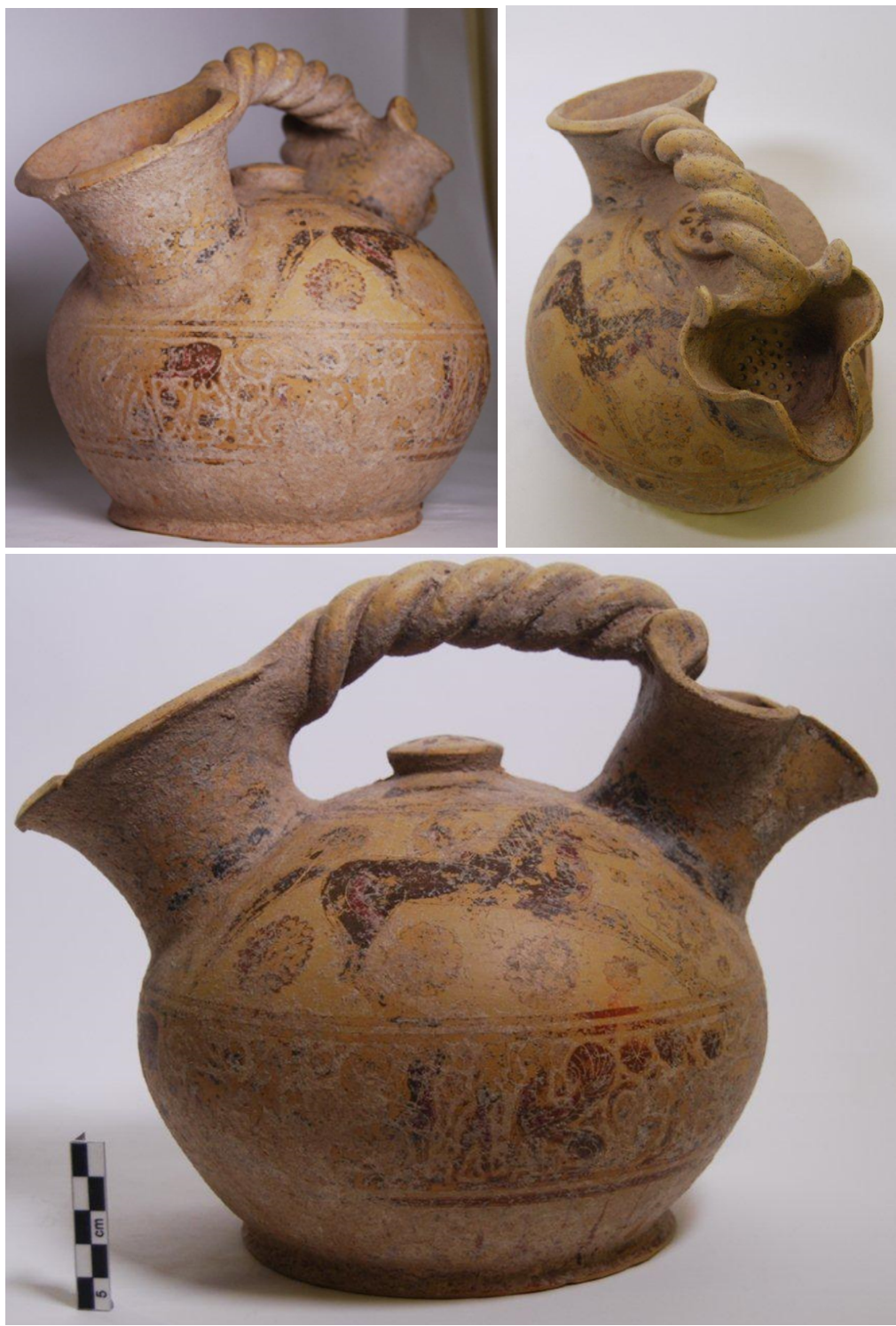

História: Questões \& Debates. Curitiba, v. 69, n. 1, p. 47-80, jan./jun. 2021. Universidade Federal do Paraná. ISSN: 0100-6932. DOI: http://dx.doi.org/10.5380/his.v00i0.000000 
Fig. 9, 10 and 11 - Designs of the scenes depicted on the double spouted askos.
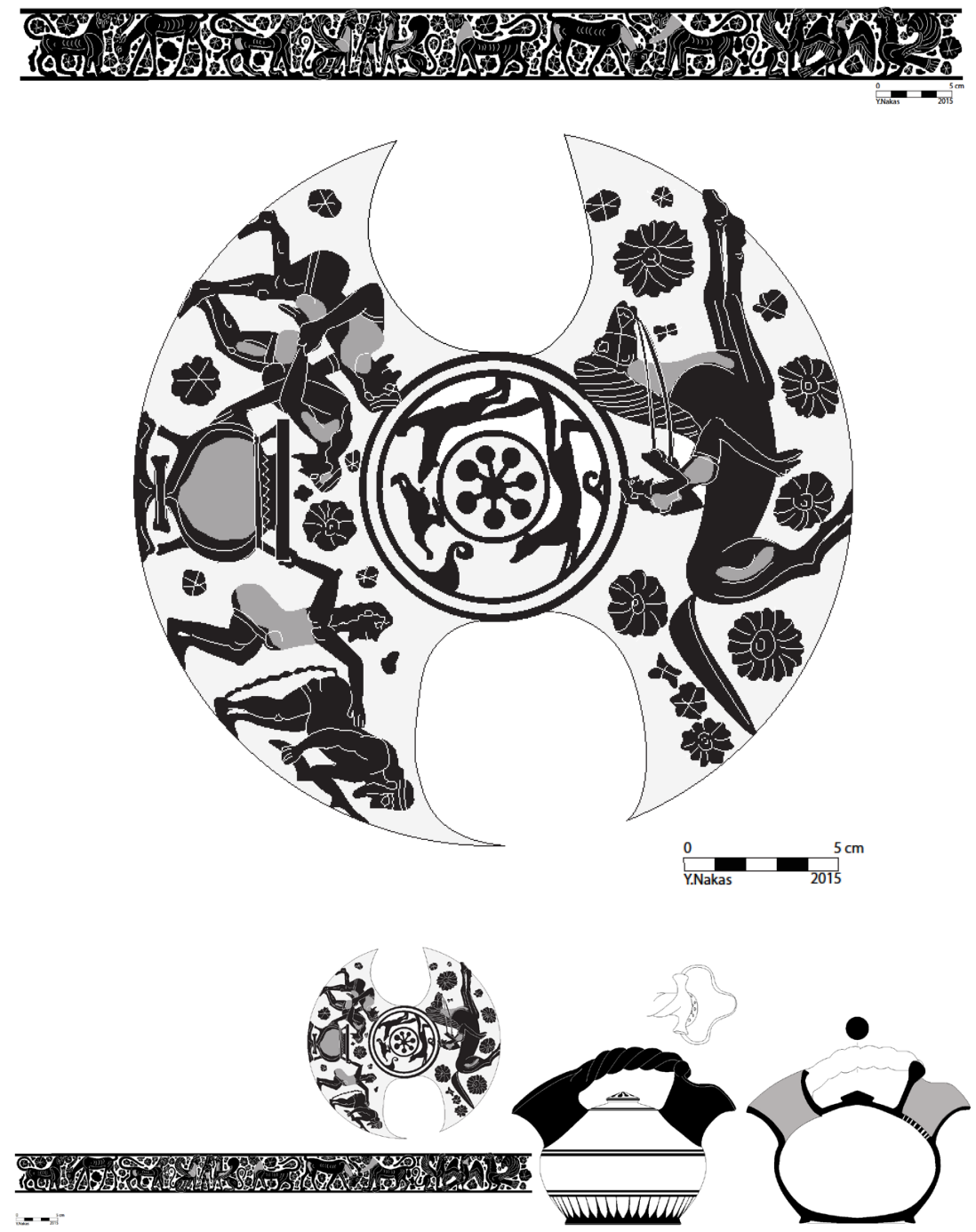
Fig. 12 - Two Kouroi from Tenea at Corinth, Archaeological Museum.

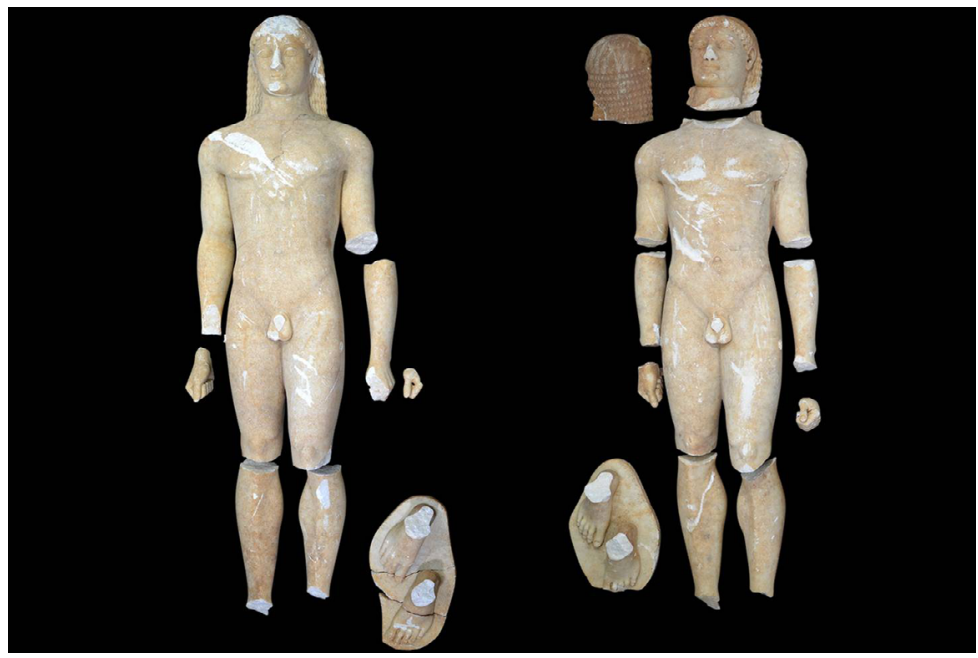

Fig. 13 - Kouros from Tenea at Munich, Glyptothek

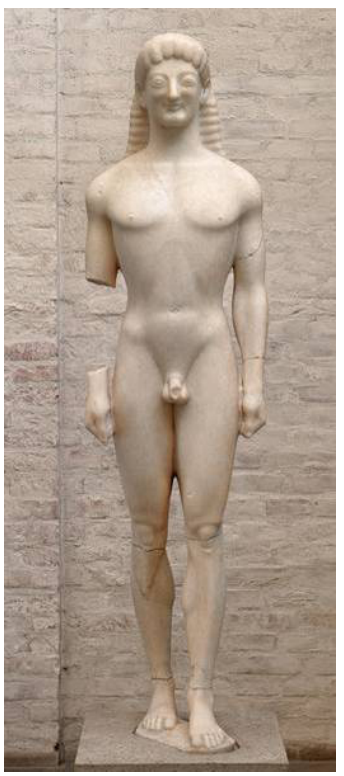




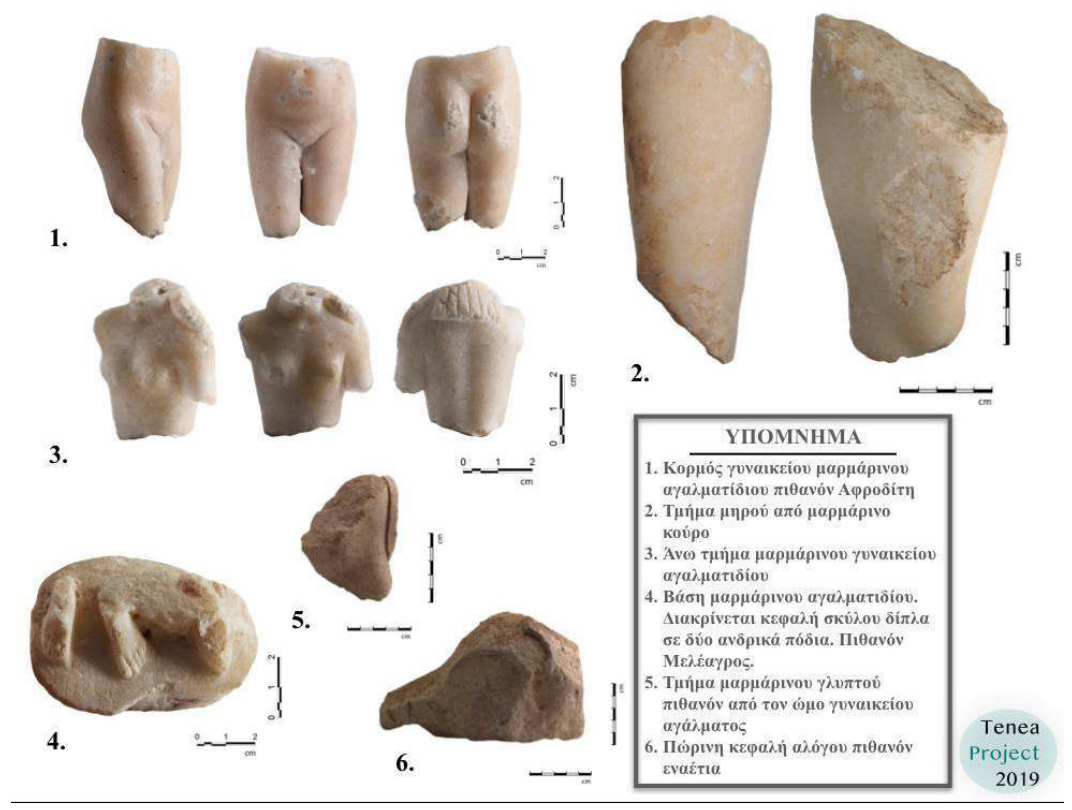

Fig. 14, no. 1 - Fragment of small statuette of Knidian Aphrodite, at Chiliomodi, Storeroom.

Fig. 14, no. 2 - Fragment of Apollo perhaps of the Omphalos type, at Chiliomodi, Storeroom. Fig. 14, no. 3 - Fragment of Aphrodite Stephanusa, at Chiliomodi, Storeroom.

Fig. 14, no. 4-Fragment perhaps of the Skopadic type of Meleager, at Chiliomodi, Storeroom. Fig. 14, no. 5 - Fragment perhaps of Artemis or Amazon, at Chiliomodi, Storeroom.

Fig. 14, no. 6 - Angle of pediment, at Chiliomodi, Storeroom. 
Fig. 15 - Omphalos type of Apollo, Athens, National Archaeological Museum.

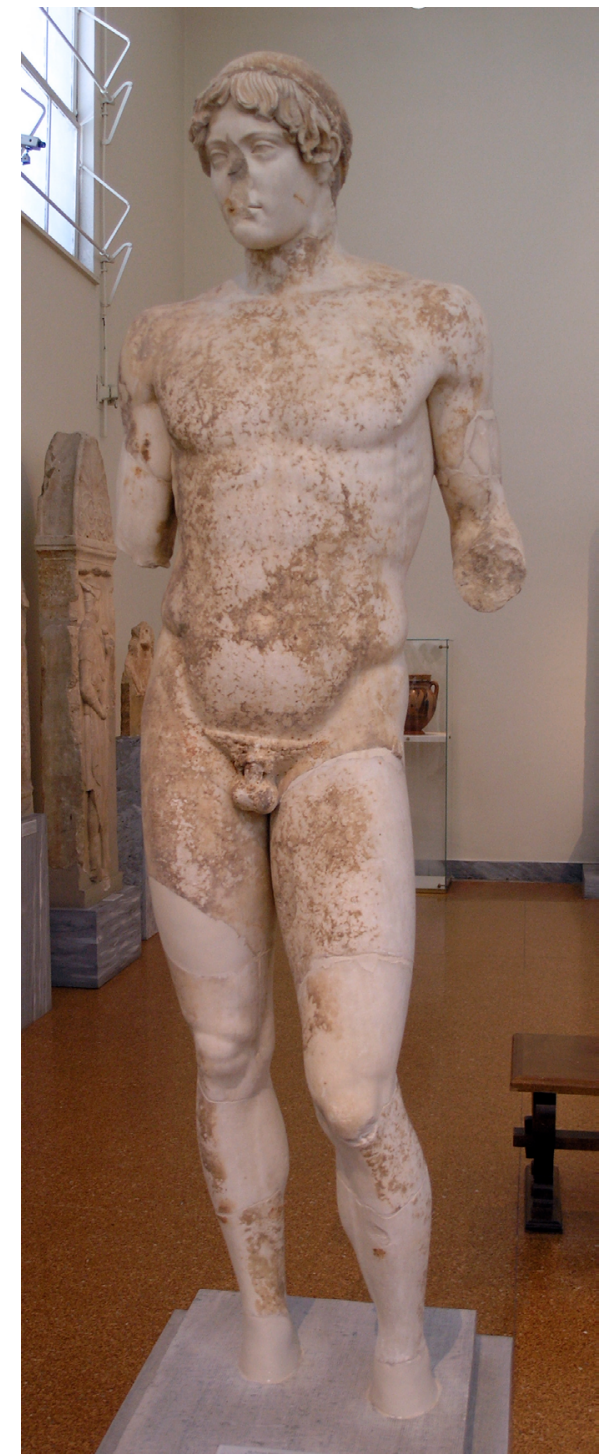

História: Questões \& Debates. Curitiba, v. 69, n. 1, p. 47-80, jan./jun. 2021. Universidade Federal do Paraná. ISSN: 0100-6932. DOI: http://dx.doi.org/10.5380/his.v00i0.000000 
Fig. 16 - Dresden Artemis, Dresden, Staatliche Museen, Skulpturensammlung.

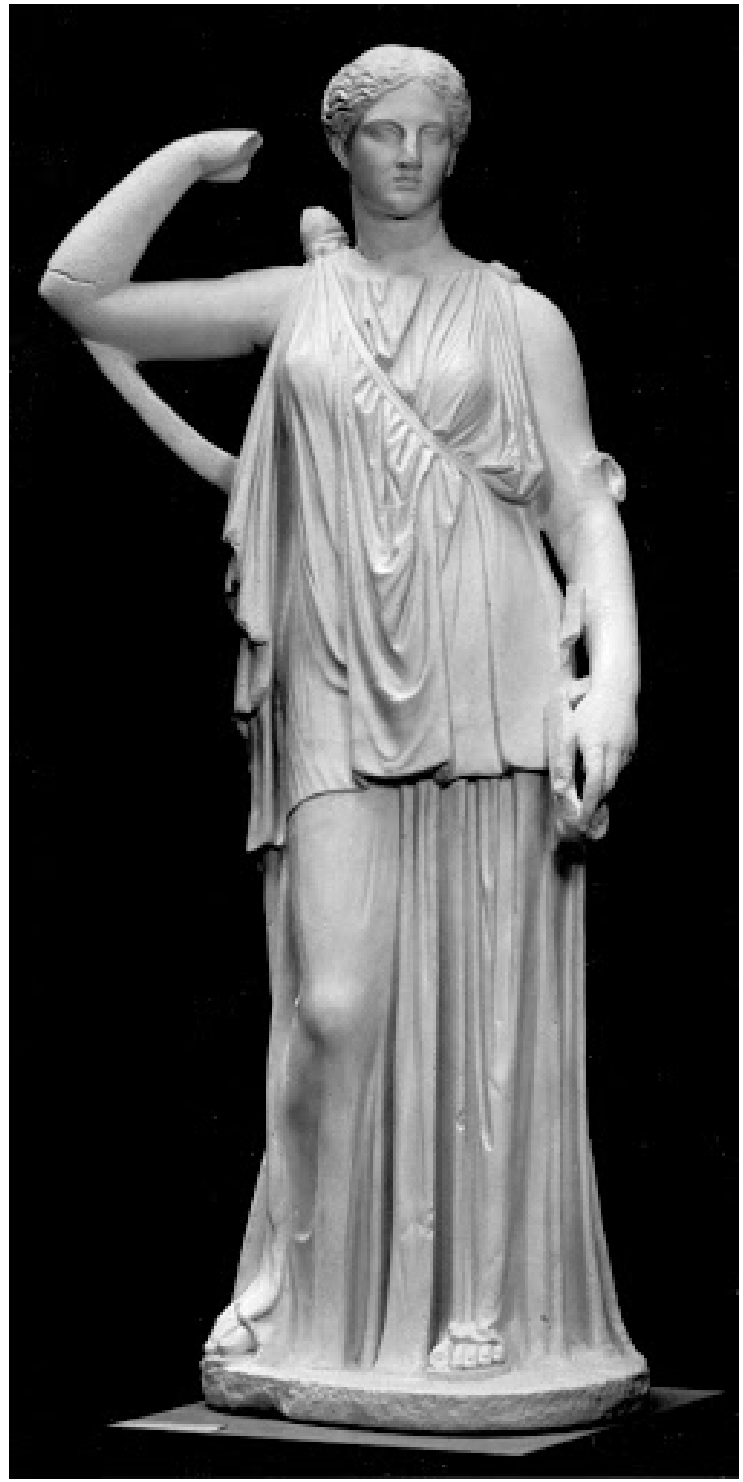

História: Questões \& Debates. Curitiba, v. 69, n. 1, p. 47-80, jan./jun. 2021. Universidade Federal do Paraná. ISSN: 0100-6932. DOI: http://dx.doi.org/10.5380/his.v00i0.000000 
Fig. 17 - Sciarra type of Amazon, Berlin, Altes Museum, Skulpturensammlung.

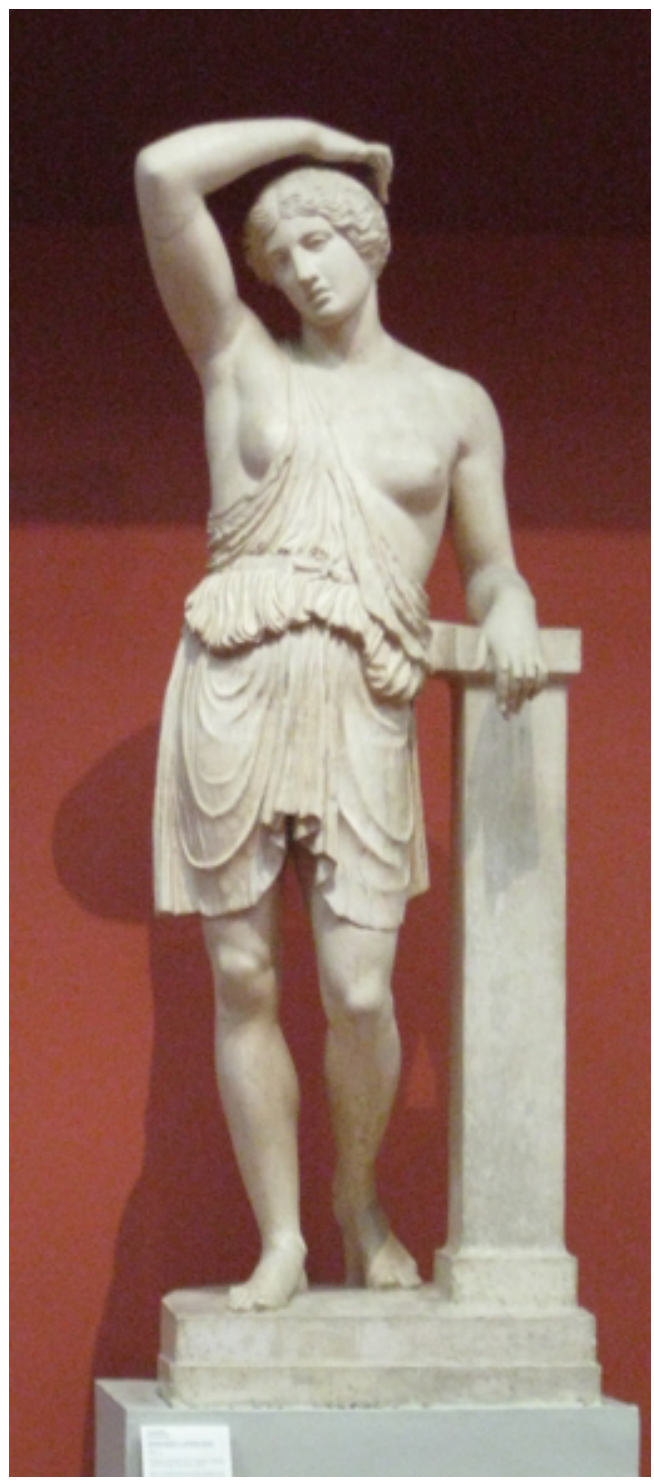

História: Questões \& Debates. Curitiba, v. 69, n. 1, p. 47-80, jan./jun. 2021. Universidade Federal do Paraná. ISSN: 0100-6932. DOI: http://dx.doi.org/10.5380/his.v00i0.000000 
Fig. 18 - Knidian Aphrodite, Colonna copy, Rome, Vatican Museums.

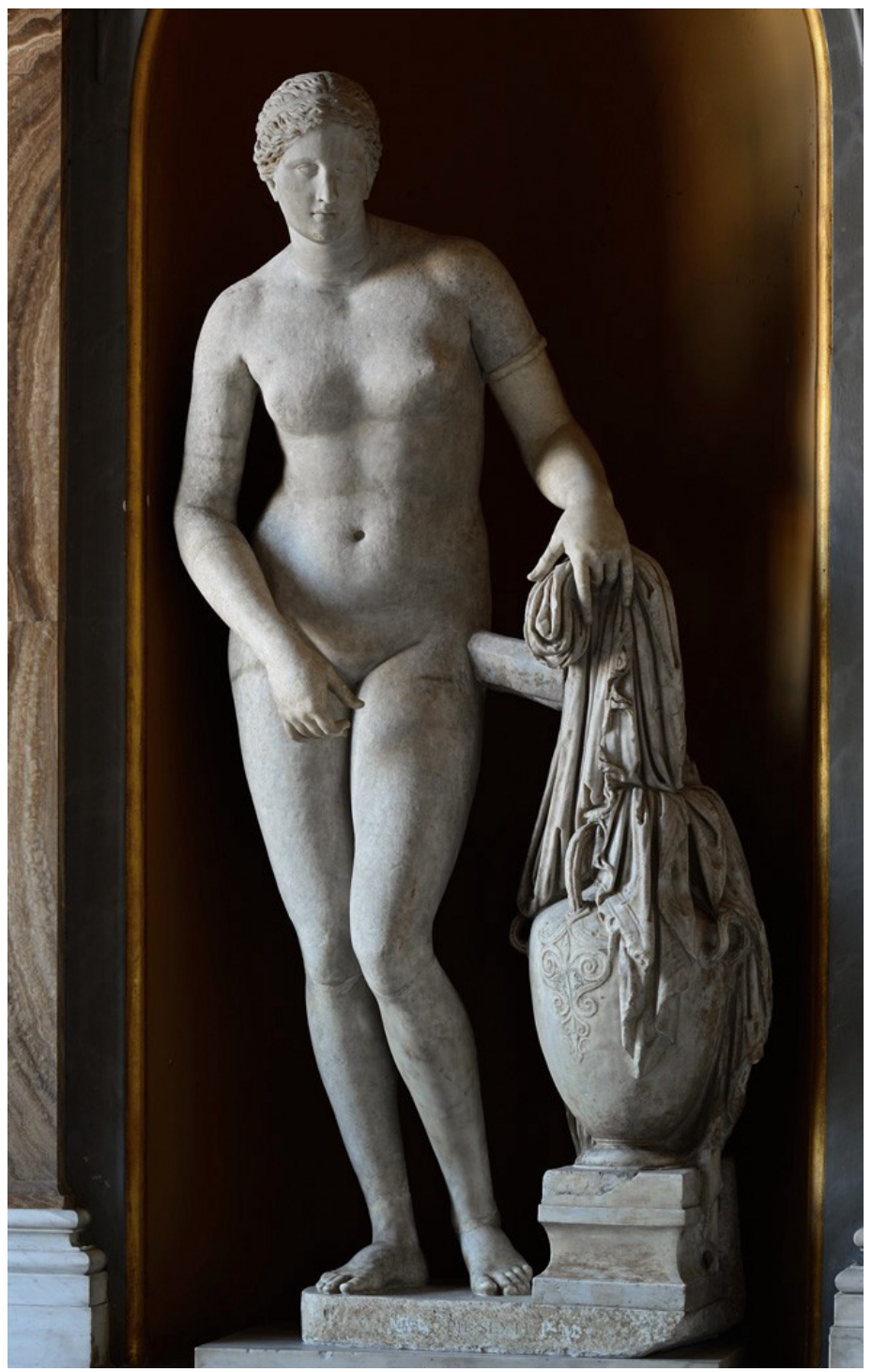

História: Questões \& Debates. Curitiba, v. 69, n. 1, p. 47-80, jan./jun. 2021. Universidade Federal do Paraná. ISSN: 0100-6932. DOI: http://dx.doi.org/10.5380/his.v00i0.000000 
Fig. 19 - Aphrodite Stephanusa, Berlin, Altes Museum, Skulpturensammlung.

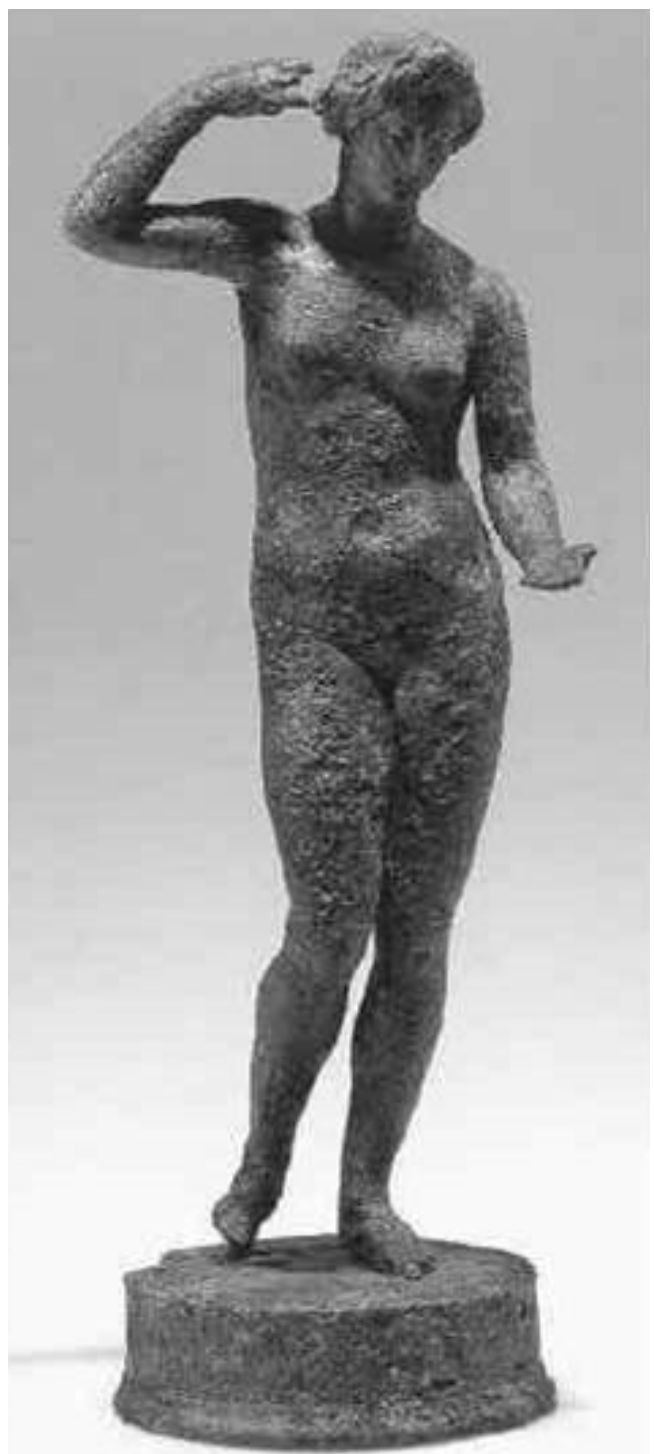

História: Questões \& Debates. Curitiba, v. 69, n. 1, p. 47-80, jan./jun. 2021. Universidade Federal do Paraná. ISSN: 0100-6932. DOI: http://dx.doi.org/10.5380/his.v00i0.000000 
Fig. 20 - Left, panel with Hermes, Corinth, Archaeological Museum.

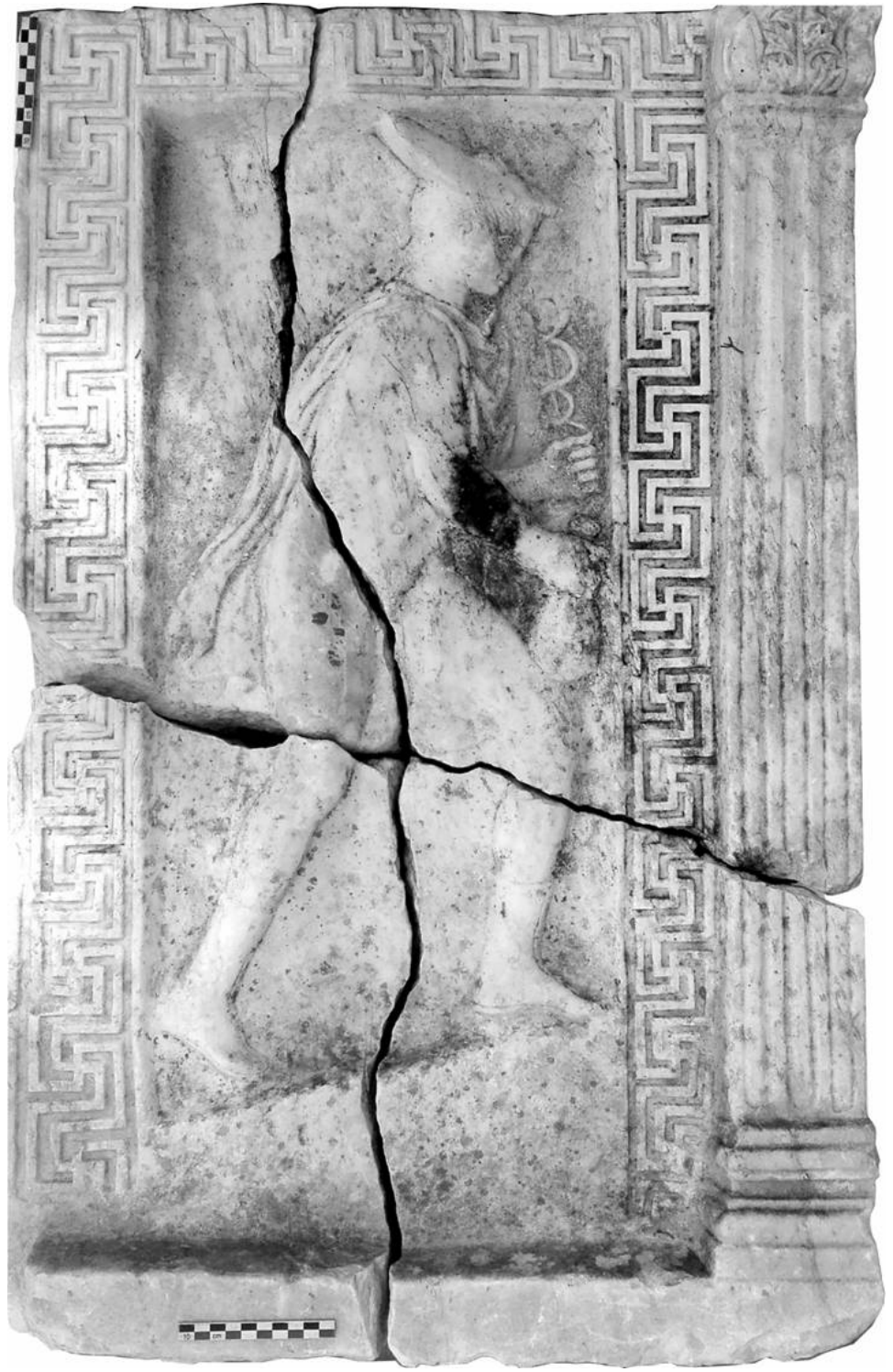

História: Questões \& Debates. Curitiba, v. 69, n. 1, p. 47-80, jan./jun. 2021. Universidade Federal do Paraná. ISSN: 0100-6932. DOI: http://dx.doi.org/10.5380/his.v00i0.000000 
Fig. 21 - Panel with Dionysos and Satyr walled in the main Church of Chiliomodi.

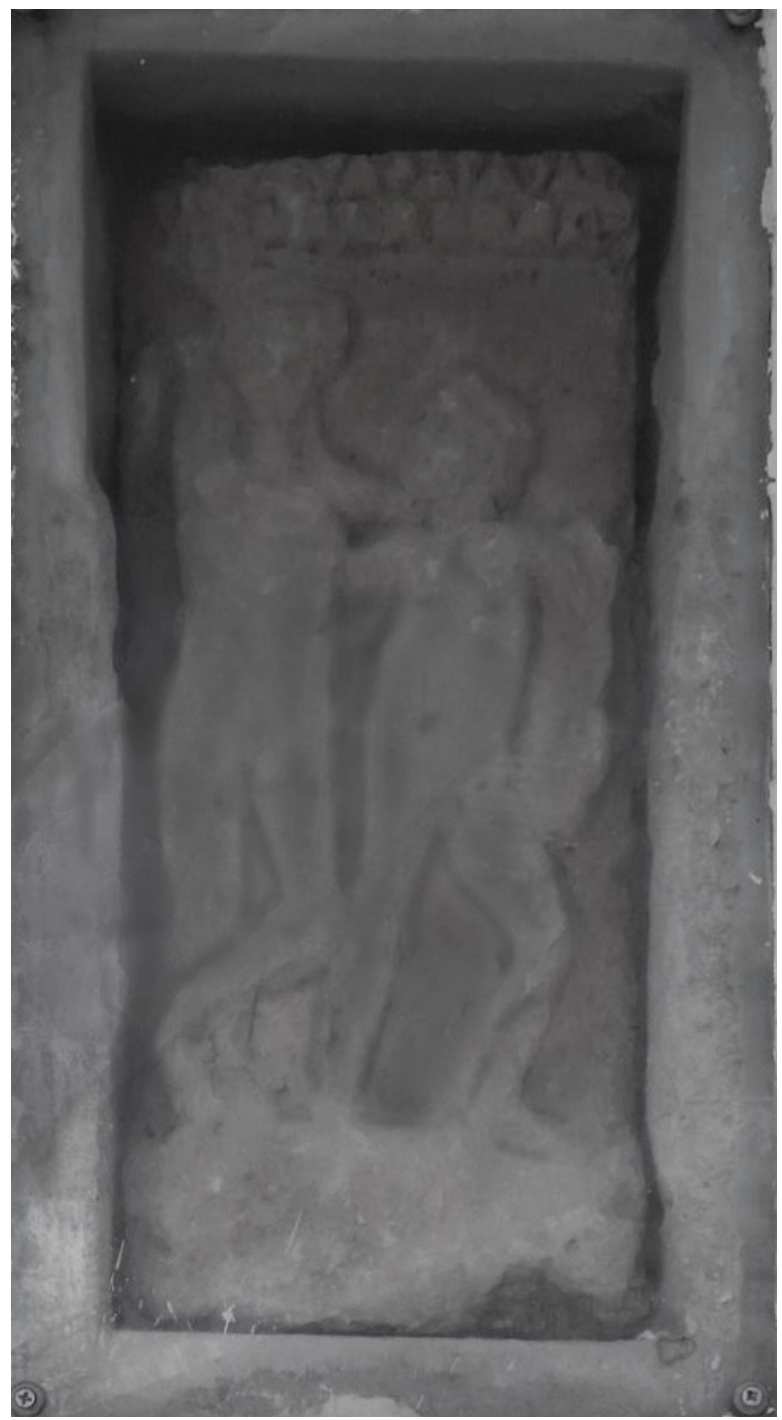

História: Questões \& Debates. Curitiba, v. 69, n. 1, p. 47-80, jan./jun. 2021. Universidade Federal do Paraná. ISSN: 0100-6932. DOI: http://dx.doi.org/10.5380/his.v00i0.000000 
Fig. 22 - Roman lamp. Aphrodite.

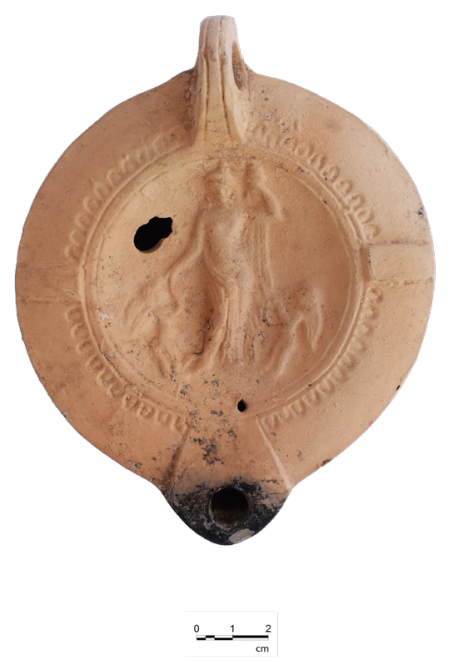

Fig. 23 - Roman lamp. Artemis Laphria.

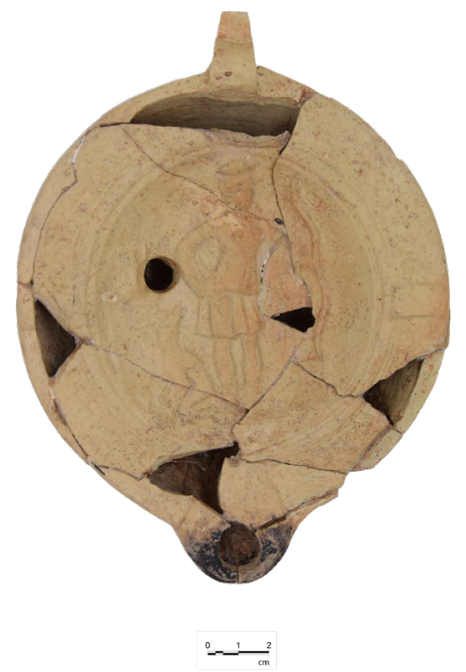

História: Questões \& Debates. Curitiba, v. 69, n. 1, p. 47-80, jan./jun. 2021. Universidade Federal do Paraná. ISSN: 0100-6932. DOI: http://dx.doi.org/10.5380/his.v00i0.000000 
Fig. 24 - Roman lamp. Hygeia.
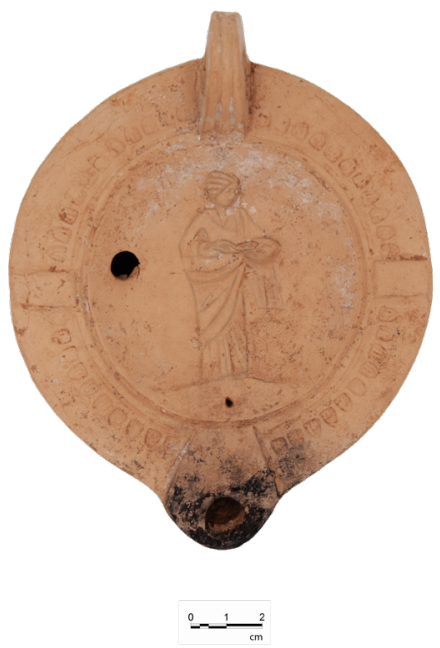

Fig. 25 - Coin.

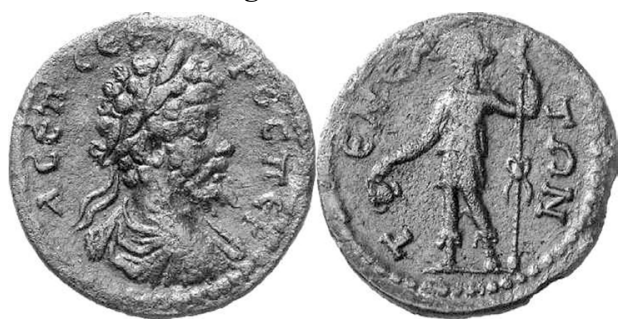

Fig. 26 - Coin.

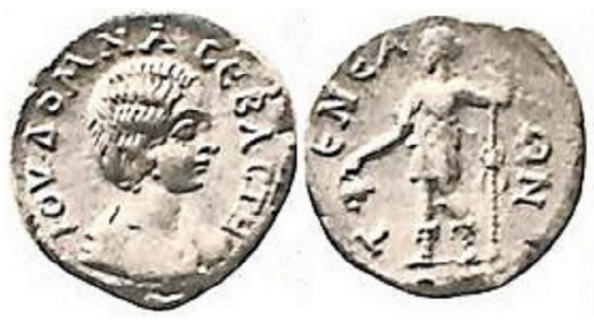

História: Questões \& Debates. Curitiba, v. 69, n. 1, p. 47-80, jan./jun. 2021. Universidade Federal do Paraná. ISSN: 0100-6932. DOI: http://dx.doi.org/10.5380/his.v00i0.000000 
Fig. 27 - Coin.

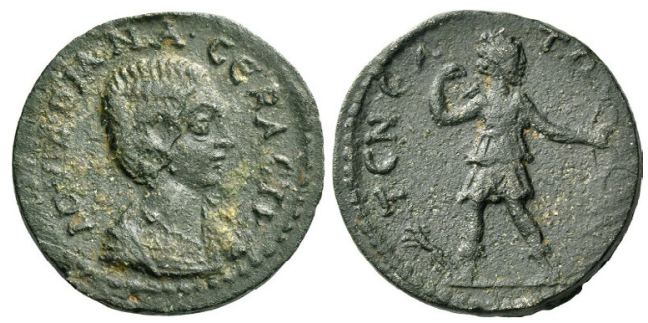

Fig. 28 - Iron ring. Representation of the god Sarapis.
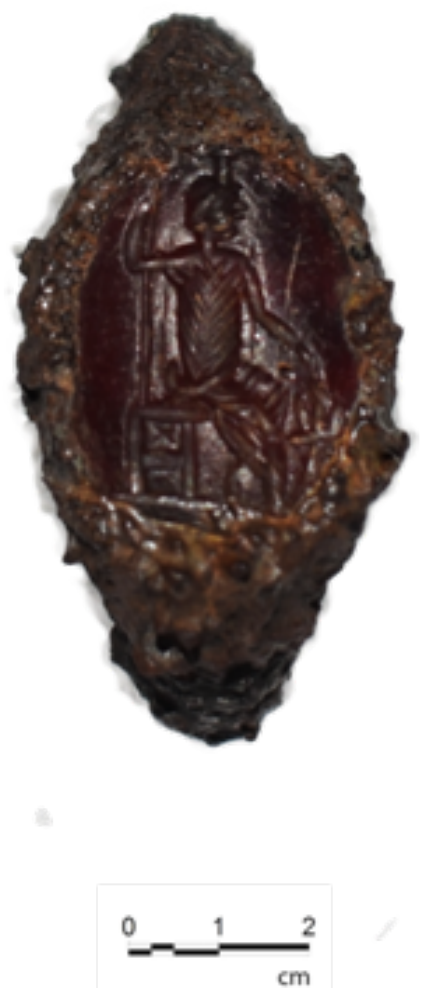

História: Questões \& Debates. Curitiba, v. 69, n. 1, p. 47-80, jan./jun. 2021. Universidade Federal do Paraná. ISSN: 0100-6932. DOI: http://dx.doi.org/10.5380/his.v00i0.000000 


\section{Bibliography}

Amyx, D.A. Corinthian vase painting of the archaic period, Berkley, University of California Press, 1988.

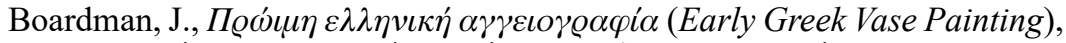

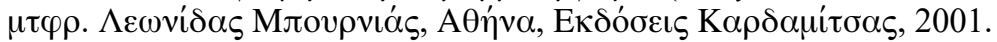

Civitello, M., "Si-mi-te-u/ $\Sigma \mu \iota v \theta \varepsilon v ́ c:$ Una testimonianza Creteze dalla Troada?" in R. Laffineur אal E. Greco (eds) EMPORIA. Aegeans in the Central and Eastern Mediterranean. Proceedings of the 10th International Aegean Conference, Athens, Italian School of Archaeology, 14-18 April 2004, Liège / Austin, Universite de Liège $\kappa \alpha$ university of Texas at Austin, (Aegaeum 25), Program in Aegean Scripts and Prehistory, 2005, 259- 268.

Corso, A., Korka, E. \& Lefantzis, M. "Archaeological Discoveries from Tenea", in Actual Problems of Theory and History of Art, Saint Petersburg State University, Lomonosov Moscow State University, and The State Hermitage Museum 8th international academic conference in St.Petersburg, УДК: 7.032(38); 904; 730ББК: 63.4; 85.13A43DOI: 10.18688/aa199-1-16, 2020, 172-179.

Corso, A. 'Retrieving the Aphrodite of Hermogenes of Cythera', Hyperboreus 21. 1, 2015, 80-89.

Corso, A. 'Retrieving the Style of Cephisodotus the Younger', Arctos 48, 2014, 109-136.

Corso, A. The Art of Praxiteles II. Rome 2007.

Corso, A. 'Praxitelean Dionysi', Eulimene 1, 2000, 25-53.

Conlin, D. A. The Artists of the Ara Pacis. Chapel Hill, 1977.

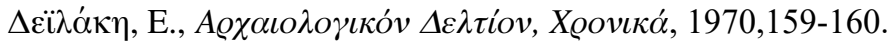

Hill, D. K. «Material on the Cult of Sarapis.», Hesperia: The Journal of the American School of Classical Studeis at Athens, Vol. 15, No 1 (Jan.-Mar.), New Jersey: The American School of Classical Studies. 1946, 60-72.

Jockey, P. 'Noither school nor koine', Regional Schools in Hellenistic Sculpture, Oxford, 1998, 177-184.

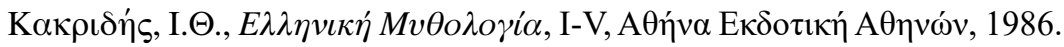

Karouzou, S. 'Der Hermes von Andros', Mitteilungen des Deutschen Archaeologischen Institut. Athenische Abteilung 84, 1969, 143-157. 
Kordosis, M. Archaia kai protobyzantini Tenea. Dodoni 26, 1997, 465-580.

Korka, E. \& Evaggeloglou, P., «A cemetery excavation unearths Tenea's past», in Beiträge zur archäologie Griechenlands 5, Griechische Nekropolen:

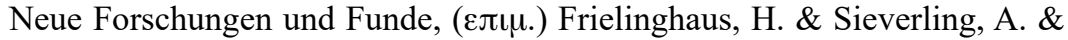
Valavanis, P., Möhnesee: Bibliopolis, 2019, 101-114.

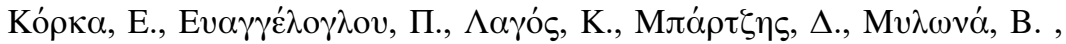

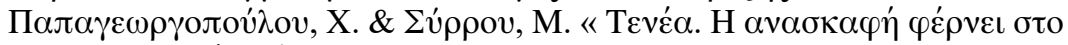

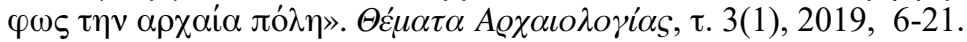

Korka, E. \& Lagos, C., "Numismatic Grave Finds of the Tenea-Chiliomodi Excavation Project 2013-2017." The Journal of Archaeological Numismatics, V. 9, 2019, 349-362.

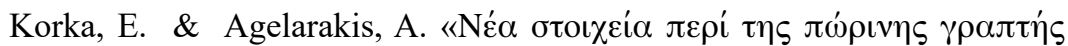

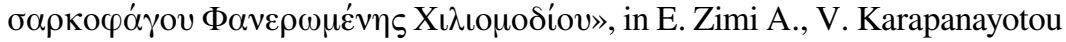

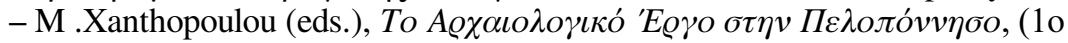

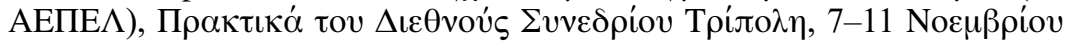
2012, Kalamata 2018, 549-556.

Ко́

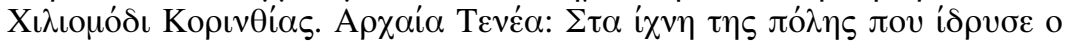

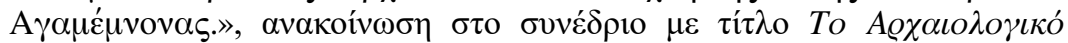

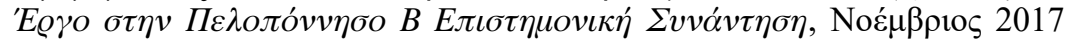
(forth coming).

Korka, E. \& Lagos, C., «New Evidence for the Coinage of Tenea», Numismatica e Antichita Classiche 47, 2018, 199-211, 203-204.

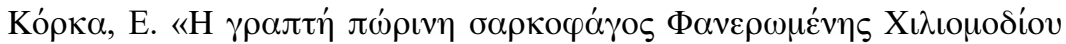

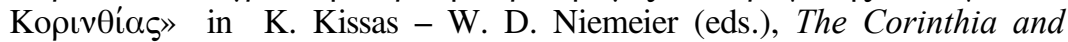
the Northeast Peloponnese, Topography and History from Prehistoric and Classical Antiquities, the LZ Ephorate of Prehistoric and Classical Antiquities, and the German Archaeological Institute, Athens, Held at Loutraki, March 26-29 2009, Athenaia 4,2013, 305-311.

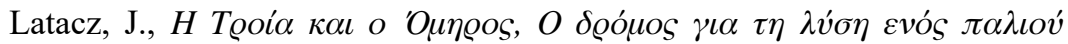

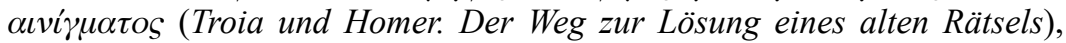

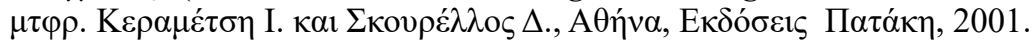

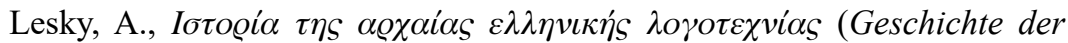

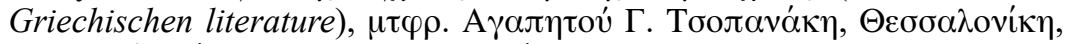

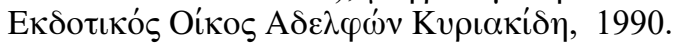


Leventi, I., Hygeia in Classical Greek Art, Archaiognosia Vol. 2. Athens, 2003. Malaise, M. , «Le calathos de Sérapis», Studien zur Altägyptischen Kultur, Bd. 38, Helmut Buske Verlag GmbH.,2009, 173-193.

Martens, B. A. , "Sarapis as Healer in Roman Athens: Reconsidering the Identity of Agora S1068.», in Autopsy in Athens : Recent Archaeological Research on Athens and Attica, (ed.) Miles, M. M., Oxford: Oxbow Books, 2015, б. 51-65.

Nagel, A., "Encountering the World of Aphrodite on the Western Greek Maniland", in eds. Smith, A.C. - Pickup, Brill's Companion to Aphrodite, S. Leiden, Boston, 2010, 235-250.

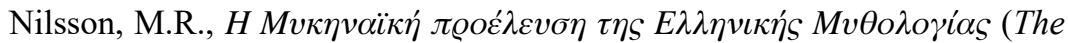

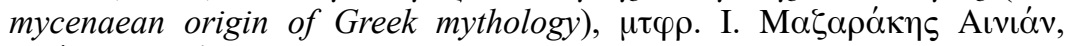

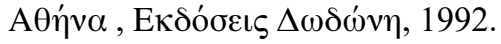

Pafumi S. 'Una nuova replica da Siracusa dell'Apollo tipo Omphalos', $B d A$ $122,2002,55-84$.

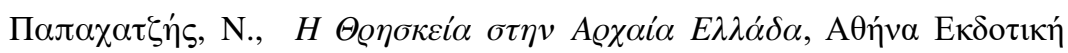
AӨๆvóv, 1996.

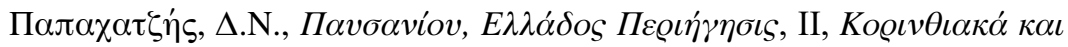

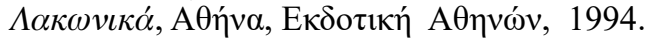

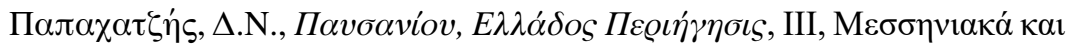

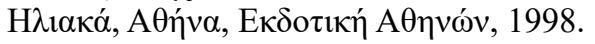

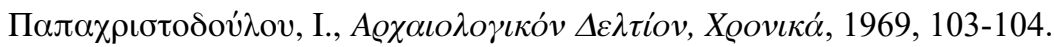

Payne, H., Necrocorinthia: A study of Corinthian art in the Archaic period, Oxford, 1931.

Pemberton ,E.G., "Wine, Woman and Song : Gender roles in Corinthian Cult", Kernos (2000), 85-106.

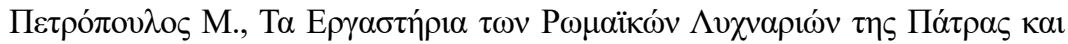

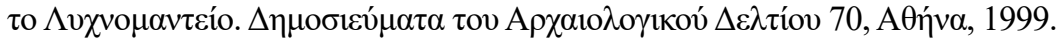

Pochmarski, E., Dionysische Gruppen, Vienna 1990.

Pullen D. and Tartaron T., "Where' s the palaces? The absence of state formation in the Late Bronze Age Korinthia" in Rethinking Mycenaean Palaces II, 2007, 146-158. 
Sauron, G., 'La promotion apollinienne de l'acanthe et la definition d'une esthetique classique a l'epoque d'Auguste', L'acanthe dans la sculpture monumentale, Paris 1993, 75-97.

Seeberg, A., Corinthian Komos Vases, University of London, Institute of Classical Studies, 1971.

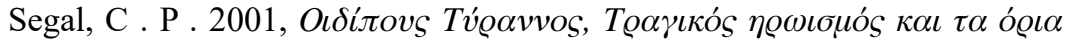

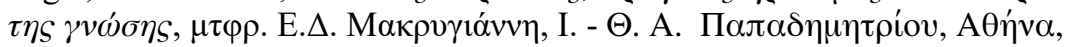

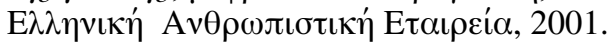

Siebert G. 'Hermes'. LIMC 5, 1990, 285-387.

Simon E. 'Mercurius', LIMC 6, 1992, 500-554.

Smith, T.J., Komast Dancers in Ancient Greek Art, Oxford, Oxford University Press, 2010.

Stambaugh, J. E., «Sarapis Under the Early Ptolemies», Études Préliminaires Aux Religions Orientales Dans L'Empire Romain, Leiden: Brill, 1972.

Stewart A. F., 'Hellenistic Freestanding Sculpture from the Athenian Agora, Part 1', Hesperia 81. 2, 2012, 267-342.

Stewart A. F. 'When is a kouros not an Apollo? The Tenea Apollo revisited', M. A. Del Chiaro (ed.), Corinthiaca, Columbia,1986, 54-70.

Stuart J. and Revett N. The Antiquities of Athens. London 1787, vol. 2.

Takács, S. A., «Isis and Sarapis in the Roman World», Religions in the Graeco-Roman World 124, Leiden: Brill,1995.

Todisco, L. Scultura greca del IV secolo, Milan 1993.

Ziskowski, A., "Clubfeet and Kypselids: Contextualising Corinthian padded dancers in the Archaic period", The Annual of the British School at Athens, Vol. 107 (2012), 211-232.

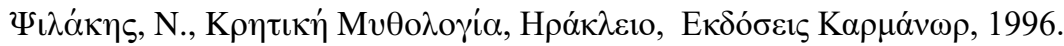

RECEBIDO EM: 04/09/2020

APROVADO EM: 24/09/2020 